\title{
Could Ctesias refer to the Kalash tribe? Some thoughts on interpretation of Ctesian descriptions of India
}

https://doi.org/10.34739/his.2019.08.14

\begin{abstract}
Indica of Ctesias is a priceless material for research into the perception of distant lands in the Greeks, or the shaping of literary images.
\end{abstract}

Key words: Indica, Ctesias, India, literary images

Indica is one of the two, next to Persica, works by Ctesias from Knidos which describes the Orient. None of the works has survived in full to the present day, they are known from copies, abbreviations, notes or comments of other authors. The relative popularity of Ctesias' works allows for a partial reconstruction of both works concerning the lands of the East, or at least giving a good image of the content of their extensive fragments. India, then understood as the northern part of the currently known subcontinent, was the source of stories that amazed with exoticism, basically fabulous. The work of Ctesias is no exception here. Therefore, it cannot be treated as a credible, direct historical source for research on ancient India. At most, it is a priceless material for research into the perception of distant lands in the Greeks, or the shaping of literary images. It is clear that Ctesias was not in India and was not the eyewitness to the phenomena he reported. He also did not speak any of the languages spoken in India. His sources were accounts translated into Persian, which was not his mother tongue either. Therefore, the collected stories were translated at least twice (one can ask a question about the quality of both processes - from one of the Indian languages into Persian (or Aramaic and from it into Persian) and from Persian into Greek. The observations were also written down long after Ctesias' return to his homeland, and it is difficult to assess the extent to which his books were written in order to satisfy the reader's expectations. It seems, however, that when confronting his messages with reality, one can suggest a real source of inspiration, whether in the form of references

\footnotetext{
* ORCID iD 0000-0002-6006-7309. anitasmyk@op.pl; Institute of History and International Relations, Faculty of Humanities.
} 
to material reality or a proper myth. Below we will present a few hypotheses concerning the relations of Ctesias.

Among the fabulous phenomena of India, described by Ctesias, many remarks are made on cynocephali or Kynoskephaloi whose tribal name the author describes as kalystrioi. The description of Ctesias gained great popularity and was repeatedly repeated as reliable, including by Marco Polo. However, can the description of a halfdog tribe living in the mountains of today's Pakistan contain elements of truth? It seems that a name rather than a sensational description can help to identify the people. Kalystrioi seems to be a transformation of the tribal name Kalash, the close-to-extinction people of northern Pakistan, known mainly for its eclectic polytheism, including Zoroastrian, Hindu and animistic features, and elements of shamanism. Kalashas, who were sometimes considered descendants of Greek settlers who came after Alexander the Great's conquests. This rather naïve and archaic view has no justification other than polytheism and the European appearance of the tribe's members. The transformation of the name Kalystroi into Kalash seems quite probable. However, the forms of shamanism or the use of ecstatic elements in rituals, with the use of animal masks, could easily become an inspiration for transforming the whole people into cynocephali. It should be added that the cult of wolves and the belief in the transformation of warriors, under the influence of ecstasy, into wolves, was widespread among numerous Indo-European peoples, including the Iranian-speaking nomads of the Great Steppe. The relative universality of lycanthropy may explain the popularity of the image of a tribe of half-humans, halfdogs, inhabiting the periphery of the world. The ritual use of animal masks, a characteristic feature of numerous manifestations of shamanism, is attested to in Kashmir, but it has become accepted in the circle of Lamaic Buddhism, lasting until the present day. At the same time, the emergence of relationships about human tribes with dog heads in Africa indicates that the Greek collective imagination has adopted this phenomenon as a feature of the 'edge of the world' areas, while they may have adopted various rationalizations, in the case of African Cynocephali it may have been early reports about baboons or remnants of early encounters with Egyptian iconography of Anubis, while the dog heads of residents of mountainous regions of India may have resulted from the distortion of ethnographic data.

Pygmies are another feature that is shared between African and Indian applications in the Ctesias' account. While in the case of Africa there may have been an adaptation of messages about the low populations of Central Africa's rainforests, in the case of India there may not have been a similar rationalisation. It also seems unlikely that Ctesias would introduce the thread on the basis of a simple analogy to stories about Africa. Although it was believed that India is linked to Africa, just as the Caucasus is linked to the Himalayas, the absence of any other elements of African fauna in India, such as hippos, zebras or lions, seems to suggest a different source of its origin. It seems that, despite the reference to the well-known motif of Greek 
folklore, the inclusion of the people of ithyphallic, bearded dwarfs living in distant regions of India, again, must have resulted from the distortion of the stories of merchants, the tributaries or the envoys.

As Bivar suggested, in relation to the late antiquity and early medieval period, in Iranian imagery, there could have existed the elements deriving from a mix of overseas relations as distant as New Zealand and Madagascar. Earlier travels over such vast distances might seem unlikely, but a sea voyage around Africa, under the auspices of Necho II, makes the relationship with deep-sea expeditions in the Achemenid period much more plausible. Considering this, we can see that the custom of wearing wooden penis extensions by the warriors from the Papua New Guinea tribes (for instance Dani, Huli, Korowei), as well as beards and hair necklaces of animal hair that resemble long beards, makes them a perfect candidate for inspiration for Ctesias. Papua warriors also often wear beards, but they don't grow very long. Among the characteristics of the Indian Pygmies, they meet the requirements of ityphallic, violent and bearded dwarves. Decreasing them to the size of dwarfs may have resulted from an exaggerated relationship with a relatively low Papua's height or a Ctesias' predilection to match the relationship to the existing stories of African Pygmies. It is also possible to speculate whether the long-beard grey-haired śaivaite ascetics were identified with the phalluses they worshipped - lingam. The Siva himself was not presented as an ascetic in ancient times in an ithyphallic form. Given the amount of distortion to which the message had to be distorted before it was edited by Ctesias, it seems most likely that there are several overlapping relationships.

The mysterious and difficult to explain creature in Indica is, according to the text, the Indus' one-toothed worm, devouring the animals that had the misfortune to approach the river bank at night. The inhabitants of India were supposed to fish for monsters with iron hooks and obtain from them a flammable substance impossible to extinguish, the possession of which was the monopoly held only by the king. The monster was explained as a gavial, which however seems very unconvincing because of the similarity between gavial and crocodile, known to the Greek reader from the descriptions of Egypt. Gavials, as a representative of crocodillia do not differ from crocodiles to such an extent as to define him as a worm. At the same time, it should be remembered that an important aspect of the description is possession of a single tooth, a feature that is difficult to attribute to the gavials, even if their narrow mouths differ from those of other crocodilia. It seems that, on the one hand, the history of the predatory giant Indus worm may be an aspect of the phenomenon of the ancient reception of the prehistoric fossil fossils of fauna, as outlined by Mayor. The single tooth of the monster seems to correspond to the construction of the skulls of the armored Silurian and Devonian fish (placodermi), which instead of teeth had a sharp bone protrusions. It is possible that the fossils of the skull of such a fish could have inspired the story of a monster with one tooth. At the same time, the issue 
of obtaining the ancient 'napalm' seems to be connected with the creation of petroleum, which, however, comes from the Permian, not the Silurian, but in areas of tectonic activity, the layers may have been mixed, hence the discovery of the fossils of Silurian fish near oil-bearing springs may have been the inspiration for the story of the single-toothed predator. It is also possible that the description of suspending a dead monster and dripping the drops of flammable substance from it may refer rather to an early method of refining crude oil. It also seems that researchers have so far overlooked the important cultural aspect of history associated with the existence of the monstrous worm in later Iranian stories describing legendary events related to the reign of Ardashir I, who killed a giant worm and overthrew a sect that professed it. Importantly, in the current context, Ardashir killed a worm by pouring molten copper into it, which corresponds to the fiery nature of the creature in Ctesias' narrative

\section{Bibliography}

BIVAR A.D.H. (2009), 'Rukhkh, Giant Eagle of the Southern Seas', in Exegisti Monumenta: Festschrift in Honour of Nicholas Sims-Williams, eds. W. SUNDERMAN, A. HINZE, F. DE BLOIS , Wiesbaden, 1-12

DAVIES G. (2016), 'Inside the isolated Indonesian Dani tribe where women are expected to ampu-tate a finger when relatives die... and the men have some rather eye-catching outfits!', Daily Mail On-Line, PUBLISHED: 11:49 BST, 17 November 2016| UPDATED: 17:10 BST, 17 November 2016.

Herodot, Dzieje, tr. S. HAMMER, Warszawa 1954.

LLEWELLYN-JONES L., ROBSON J. (2013), Ctesias' History of Persia. Tales of the Orient, London and New York.

Marko Polo, Opisanie Świata, tr. A.L. CZERNY, Warszawa 1975.

MAYOR A. (2000), The First Fossil Hunters - Dinosaurs, Mammoths, and Myth in Greek and Roman Times, Princeton.

NICHOLS A. (2011), Ctesias: On India. Introduction, translation and commentary, London and New York

STONEMAN R. (2019), The Greek Experience of India. From Alexander to the Indo-Greeks, Princeton and Oxford.

WITZEL M. (2004), 'Kalash Religion, The Rgvedic Religious System and its Central Asian and Hindukush Antecedents', in The Vedas: Texts, Language and Ritual, eds. A. GRIFFITHS, J.E.M. HOUBEN, Groningen, 581-636. 